\title{
Efek Suhu dan Waktu Simpan terhadap Kualitas Bagian Tengah Tuna Sirip Kuning Segar (Thunnus albacares)
}

\author{
Debriga Putra $^{1 *}$, Henny A. Dien ${ }^{2}$, Roike Iwan Montolalu ${ }^{2}$, Daisy M. Makapedua ${ }^{2}$, \\ Hens Onibala ${ }^{2}$, Deiske A. Sumilat ${ }^{3}$, Alfret Luasunaung ${ }^{4}$ \\ ${ }^{1)}$ Program Studi Magister Ilmu Perairan, \\ ${ }^{2)}$ Program Studi Teknologi Hasil Perikanan, Jurusan Pengolahan Hasil Perikanan, \\ ${ }^{3)}$ Program Studi Ilmu Kelautan, Jurusan Manajemen Sumberdaya Perairan, \\ ${ }^{4)}$ Program Studi Pemanfaatan Sumberdaya Perairan, Jurusan Pengolahan Hasil Perikanan, \\ Fakultas Perikanan dan Ilmu Kelautan, Universitas Sam Ratulangi, Manado. \\ *Korespondensi: debrigaputra@gmail.com \\ (Diterima 23-07-2020; Direvisi 04-08-2020; Dipublikasi 06-08-2020)
}

\begin{abstract}
Decline quality of Tuna as a result of abuse temperature and long shelf life time. Histamine, microbial and sensory odours become one of the global problems that can cause health problems. Large number of bacteria dominated in viscera area rather than other fish parts. This study was conducted to determine the effect of storage temperature on histamine, microbial and sensory odours on middle of Yellowfin Tuna. This study used descriptive explorative method, sampel were periodically taken for analyses at intervals 48 hours $\left(0^{\circ} \mathrm{C}\right), 8$ hours $\left(10^{\circ} \mathrm{C}\right)$ and 4 hours $\left(25^{\circ} \mathrm{C}\right)$. Yellowfin Tuna was rejected earlier by the sensory odours than TPC and histamine. During storage at $0^{\circ} \mathrm{C}$ for 720 hours histamine levels still acceptable for consumption however TPC already exceeded the limit after 672 hours and rejected by sensory odours for 624 hours storage. During storage at temperature $10^{\circ} \mathrm{C}$ did not reached the limit for 120 hours while TPC value already reached $2 \times 10^{6} \mathrm{cfu} / \mathrm{g}$ for 88 hours storage and rejected by sensory odours for 72 hours storage. During storage at temperature $25^{\circ} \mathrm{C}$ histamine reached $67.3 \mathrm{ppm}$ for 32 hours, ALT reached $5.5 \times 10^{5} \mathrm{cfu} / \mathrm{g}$ for 24 hours and rejected by sensory odour for 20 hours of storage. Histamine formation correlates with the growth of microbial counts and decrease of sensory odours value.
\end{abstract}

Keywords: $\quad$ Tuna quality, Histamine, TPC and Sensory odours.

Suhu yang tinggi dalam waktu simpan lama berpengaruh terhadap penurunan kualitas ikan tuna. Histamin, mikroba dan bau busuk menjadi salah satu permasalahan global yang dapat menyebabkan masalah kesehatan. Bagian tengah ikan menjadi sumber bakteri paling tinggi dibandingkan bagian lainnya. Penelitian ini bertujuan untuk mengkaji perkembangan histamin, ALT dan sensori bau pada bagian tengah Tuna sirip kuning dalam penyimpanan suhu yang berbeda. Penelitian ini menggunakan metode deskriptif eksploratif, sample di analisis secara berkala pada suhu $0^{\circ} \mathrm{C}(48 \mathrm{jam}), 10^{\circ} \mathrm{C}(8 \mathrm{jam}) \mathrm{dan}$ $25^{\circ} \mathrm{C}$ (4 jam). Tuna sirip kuning mengalami pembusukan lebih awal berdasarkan parameter sensori bau, kemudian disusul ALT dan Histamin. Kandungan histamine pada suhu $0^{\circ} \mathrm{C}$ masih layak untuk dikonsumsi setelah 720 jam, namun nilai ALT melebihi batas aman setelah 672 jam penyimpanan dan nilai sensori bau setelah 624 jam penyimpanan. Penyimpanan suhu $10^{\circ} \mathrm{C}$ tidak menyebabkan peningkatan histamin melebihi batas limit setelah penyimpanan selama 120 jam, sedangkan nilai ALT mencapai $2 \times 10^{6} \mathrm{cfu} / \mathrm{g}$ setelah $88 \mathrm{jam}$ dan nilai sensori bau menyatakan ikan busuk setelah penyimpanan selama 72 jam. Penyimpanan suhu $25^{\circ} \mathrm{C}$ histamin mencapai $67,3 \mathrm{ppm}$ setelah penyimpanan $32 \mathrm{jam}$ dan nilai ALT $5,5 \times 10^{5} \mathrm{cfu} / \mathrm{g}$ pada penyimpanan ke 24 jam serta ikan dinyatakan busuk berdasarkan sensori bau setelah 20 jam penyimpanan. Peningkatan histamin berkorelasi dengan pertumbuhan jumlah mikroba dan penurunan nilai sensori bau.

Kata kunci: Kualitas Tuna, Histamin, ALT, Sensori bau.

\section{PENDAHULUAN}

Ikan Tuna (Thunnus sp) merupakan komoditas perikanan Indonesia yang memiliki nilai ekonomis tinggi dan mampu menembus pasar internasional. Indonesia adalah peringkat ke lima eksportir Tuna terbesar di dunia sekitar 55,300 ton pada tahun 2017 dan meningkat menjadi 59,500 ton (FAO, 2019). Mengingat negara maju sangat peka dalam hal mutu dan keamanan produknya, sehingga standar yang ditetapkan sering tidak sejalan dengan beberapa industri, sehingga dapat menyebabkan penolakan produk perikanan Indonesia di negara importir (Maulana et al., 2012). Penyebab penolakan produk Indonesia diantaranya adalah karena kandungan histamine dan bakteri pathogen yang melewati batas standar (Irawati et al., 2019).

Putra $d k k ., 2020$

Suhu, Thunnus albacares, Kualitas, Tuna 
Ikan mengandung protein dan air yang tinggi, sehingga termasuk pangan yang mudah rusak (perishable food) dan menurun mutunya (Nurjanah et al., 2011). Peraturan dalam kegiatan ekspor Tuna menetapkan bahwa keracunan scombroid histamin menjadi masalah global pada penangkapan, pengolahan dan pendistribusian produk seafood (Tao et al., 2002). Histamin merupakan degradasi mikroba dari asam amino histidine karena aktivitas dari enzim L-Histidine decarboxylase (Cinquina et al., 2004). Kandungan histidine Tuna sirip kuning menurut Suyama and Yozhiazawa dalam Biji et al. (2016) yaitu $122 \mathrm{mg} / 100 \mathrm{~g}$ sedangkan menurut Mangunwardoyo et al. (2007) yaitu $740 \mathrm{mg} / 100 \mathrm{~g}$, histamine terbentuk jika ikan mengandung histidine bebas di atas $100 \mathrm{mg} / 100 \mathrm{~g}$. Histamin terjadi pada suhu yang tinggi dalam jangka waktu yang lama, hal ini berhubungan dengan penurunan kualitas ikan (FDA, 2019). Proses kemunduran bisa diperlambat dengan pendinginan, penurunan suhu dari $5^{\circ} \mathrm{C}$ ke $0^{\circ} \mathrm{C}$ dapat mengurangi separuh laju pembusukan (Starling \& Diver, 2005). Sampel yang disimpan pada suhu $4^{\circ} \mathrm{C}$ memiliki tingkat histamin yang dapat diabaikan (Tahmouzi et al., 2013) dengan suhu optimum aktivitas dekarboksilasi histidine $2^{\circ}-30^{\circ} \mathrm{C}$ (Lehane \& Olley, 2000).

Selain permasalahan histamin, jumlah mikroba dan bau busuk pada Tuna juga menjadi masalah Kesehatan dan penolakan produk, karena kontaminasi bakteri selama proses penangkapan, penanganan dan pengolahan (Wodi et al., 2018). Pertumbuhan mikroba menyebabkan kemunduran mutu ikan yang salah satunya ditandai dengan perubahan bau (Wodi et al., 2016). Evaluasi sensori telah lama digunakan untuk mengukur tingkat dekomposisi pada ikan, namun tidak cukup jika hanya menggunakan parameter sensori (DiGregorio, 2012; FAO/WHO, 2012; FDA, 2019). Korelasi antara kandungan histamin dan bau sering tidak konsisten, seperti pembentukan histamin tanpa signifikan bau (FAO/WHO, 2012) dan terdeteksi bau tanpa peningkatan histamin (Du et al., 2002). Kandungan histamine dan Mikroba gutted Tuna lebih tinggi dari pada non-gutted yang disimpan dalam beberapa temperatur dikarenakan jumlah bakteri lebih tinggi pada bagian isi perut dibandingkan bagian lainnya (Mahusain et al., 2016). Penelitian dilakukan untuk mengetahui pengaruh suhu dan lama penyimpanan terhadap pembentukan histamin, total bakteri dan sensori bau pada bagian tengah Tuna sirip kuning.

\section{MATERIAL DAN METODE}

\section{Alat dan Bahan}

Alat yang digunakan antara lain styrofoam, timbangan, plastik wadah sampel, pisau, talenan, pipettor, timer, botol cuci wadah wash buffer, pipettor 8 channel, stat fax, blue labelled reagent, green labelled reagent boat, red labelled reagent boat, well holder, stomacher, inkubator.

Bahan utama pada penelitian ini adalah Tuna sirip kuning Segar grade A berat $45 \mathrm{~kg}$ yang diambil dari perusahaan ekspor ikan Tuna PT. Blue Ocean Grace International, Bitung. Bahan kimia yang digunakan antara lain : butterfield's phosphate buffered, plate count agar, akuades, wash buffer, diluent buffer, substrat solution.

\section{Preparasi Sampel}

Pengecekan suhu ikan pada saat penerimaan adalah $1,7^{\circ} \mathrm{C}$, kemudian diproses menjadi loin, lalu diambil sebagai sampel pada bagian tengah tubuh ikan (dipotong menjadi steak). Sampel disimpan menggunakan plastik High Density Poly Ethylene kemudian dimasukkan dalam Styrofoam yang berisi jelly ice. Jelly ice melapisi semua bagian sampel pada bagian bawah dan atas. Kemudian sampel ditransfer ke Laboratorium Badan Karantina Ikan Pengendalian Mutu dan Keamanan Hasil Perikanan (BKIPM) untuk analisis ALT dan sensori bau, sedangkan pengujian histamin dilakukan di laboratorium PT. BOGI dengan perjalanan \pm 5 menit. Analisis pengujian dilakukan secara berkala setiap 48 jam $\left(0^{\circ} \mathrm{C}\right), 8$ jam $\left(10^{\circ} \mathrm{C}\right)$ dan 4 jam $\left(25^{\circ} \mathrm{C}\right)$.

\section{Uji Histamine}

Veratox untuk pengujian histamin adalah competitive direct enzyme-linked immunosorbent assay (CD-ELISA). Veratox Quantitative Histamine test Tuna Pack Neogen Corporation, 620 Lesher Place, Langsing MI 48912 USA, berdasarkan AOAC Official Methods, certificate No, 070703. $10 \mathrm{~g}$ sampel dihomogenkan dengan $90 \mathrm{ml}$ akuades. Kocok selama 20 detik dan diamkan selama 5 menit (langkah ini dilakukan 3 kali). $100 \mu$ ekstrak hasil saringan atau supernatant dituang ke dalam $10 \mathrm{ml}$ dari ekstrak diluent buffer ditambahkan ke tabung reaksi yang bersih. Warna merah 
pada wells adalah mixing well dan warna putih well adalah antibody-coated wells. $100 \mu \mathrm{l}$ dari conjugate ditambahkan pada red-marked mixing well strips. Masing-masing $100 \mu$ l digunakan sebagai kontrol $(0,2.5,10,20$ dan $50 \mathrm{ppm}$ konsentrasi histamin) sampel dipindahkan ke redmarked mixing wells lalu dipipet naik turun sebanyak 3 kali. $100 \mu \mathrm{l}$ dari campuran di atas dipindahkan ke antibody-coated microwells dan didiamkan selama 10 menit. Campur dengan menggeser well holder maju mundur pada permukaan yang datar selama 10-20 detik tanpa memercikkan reagent dari well lalu inkubasi selama 10 menit pada suhu $18-30^{\circ} \mathrm{C}$. lalu buang redmarked mixing well.

Isi dari antibodi well dikeluarkan dan diisi dengan wash buffer lalu dibuang (dilakukan sebanyak 3 kali). Kemudian balik well (atas ke bawah) dan keluarkan cairan yang tersisa. Gunakan pipette tips baru dan pipet $100 \mu \mathrm{l}$ substrat dari green-labelled bottle dan masukkan ke dalam well. Tuang secukupnya red stop solution ke red labelled reagent boat. Gunakan pipette tips baru dan ambil $100 \mu \mathrm{l}$ substrat red-stop solution dari red labelled reagent boat ke dalam well dan campurkan dengan menggeser maju mundur di atas permukaan datar. Usap bagian bawah well dengan tisu dan baca dengan menggunakan stat fax pada panjang gelombang $650 \mathrm{~nm}$ filter.

\section{Uji Angka Lempeng Total (BSN, 2015)}

$25 \mathrm{~g}$ sampel dihomogenkan dalam $225 \mathrm{ml}$ larutan Butterfield's Phospate Buffered (BPB). Homogenate merupakan larutan pengenceran $10^{-1}$. Sebanyak $1 \mathrm{ml}$ homogenate diambil menggunakan pipet steril dimasukkan ke dalam botol berisi $9 \mathrm{ml}$ larutan BPB untuk mendapatkan pengenceran $10^{-2}$, lakukan hal yang sama untuk pengenceran $10^{-3}, 10^{-4}, 10^{-5}, 10^{-6}$ dan $10^{-7}$. Tahap pengujian, pipet sebanyak $1 \mathrm{ml}$ pada setiap pengenceran dan dimasukkan ke dalam cawan petri yang steril secara duplo untuk setiap pengenceran. Pada setiap cawan petri ditambahkan $15 \mathrm{ml}$ media Plate Count Agar (PCA). Inkubasi cawan-cawan tersebut dalam posisi terbalik pada suhu $35^{\circ} \mathrm{C}$ selama 48 jam. Selanjutnya dilakukan pengamatan dengan menghitung jumlah koloni bakteri pada cawan petri. Jumlah koloni yang dihitung adalah antara 25-250 koloni.

\section{Evaluasi Sensori}

Sensori bau salah satu cara efektif untuk mendeteksi ikan yang telah mengalami kondisi penanganan yang tidak baik (FDA, 2019). Indikator kualitas sensori berdasarkan U.S Department of Commerce. Kualitas sensori bau menggunakan skala angka 1-100. 1 adalah sangat segar dan 100 adalah sangat busuk. Kualitas sangat segar seperti bau rumput laut, ketimun atau melon dengan skala angka $0-25$, sedangkan mulai bau busuk setelah tercium bau masam, fermentasi, ragi, plastik atau bahan kimia dengan skala angka 51-55. Jumlah panelis yang digunakan yaitu 6 panelis yang tersertifikasi oleh seafood inspection laboratory dan merupakan para grader di industri tuna.

\section{Analisa Data}

Data hasil analisis perkembangan kadar histamin pada masing-masing suhu menggunakan analis deskripsi. Korelasi antara peningkatan histamin kaitannya dengan peningkatan total mikroba dan penurunan nilai sensori bau menggunakan program IBM SPSS Statistic, Analisa yang digunakan adalah correlation coefficient (Pearson).

\section{HASIL DAN PEMBAHASAN}

\section{Histamin}

Kadar histamine bahan baku yang digunakan yaitu $0 \mathrm{ppm}$. Pembentukan histamin tidak signifikan setelah penyimpanan selama 720 jam pada suhu $0^{\circ} \mathrm{C}$ yaitu $1,8 \mathrm{ppm}$. Peningkatan histamin pada bagian tengah Tuna sirip kuning yang disimpan pada suhu $10^{\circ} \mathrm{C}$ masih sangat kecil pada 88 jam pertama, namun setelah itu mulai terjadi peningkatan histamin secara bertahap hing ga mencapai $30 \mathrm{ppm}$ setelah 120 jam, meskipun kadar histamin masih dalam batas aman sesuai dengan FDA, (2019) yaitu $<50 \mathrm{ppm}$. Kadar histamine pada penyimpanan suhu $25^{\circ} \mathrm{C}$ mencapai 67,3 ppm setelah $32 \mathrm{jam}$. Kandungan histamin pada bagian tengah Tuna sirip kuning dalam penyimpanan suhu 0,10 dan $25^{\circ} \mathrm{C}$ dapat dilihat pada Gambar 1, 2 dan 3.

Pembentukan histamin yang disimpan pada suhu $0^{\circ} \mathrm{C}$ tidak signifikan dan dapat diabaikan, hal ini sesuai dengan Tahmouzi et al. (2013) bahwa sampel yang disimpan pada suhu $4^{\circ} \mathrm{C}$ memiliki kadar histamin yang dapat diabaikan dan sejalan dengan Jinadasa et al. (2015) bahwa histamin 
dapat dikontrol dengan penyimpanan suhu 0 atau lebih rendah dari $4^{\circ} \mathrm{C}$. Hansamali et al. (2020) juga menyatakan kandungan histamin masih aman dikonsumsi setelah penyimpanan selama 15 hari pada suhu $0-2^{\circ} \mathrm{C}$. Suhu sangat berpengaruh terhadap pembentukan histamin (FDA, 2019) dimana penurunan suhu dari $5 \mathrm{ke} 0^{\circ} \mathrm{C}$ dapat mengurangi separuh tingkat kerusakan pada ikan (Starling \& Diver, 2005) dan Menurut Lehane \& Olley (2000) bahwa aktivitas dekarboksilasi histidine terjadi jika suhu lebih besar dari $5^{\circ} \mathrm{C}$ dengan suhu optimum $20-30^{\circ} \mathrm{C}$. Suhu tinggi mempercepat pembentukan histamin dan penyimpanan dingin yang tepat $<4^{\circ} \mathrm{C}$ akan menghambat pembentukan histamin (Du et al., 2002).

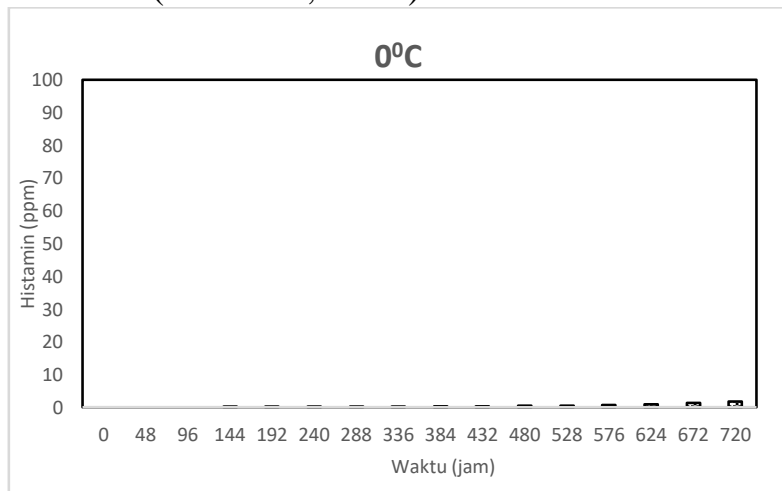

Gambar 1. Kandungan histamin penyimpanan suhu $0^{\circ} \mathbf{C}$.

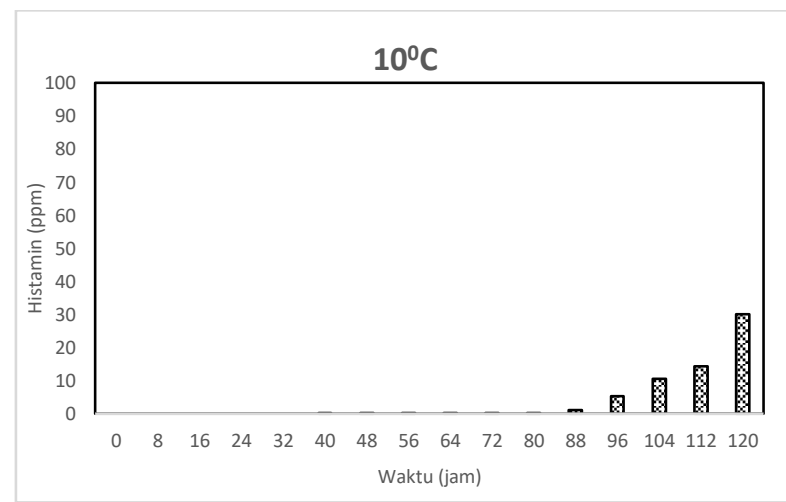

Gambar 2. Kandungan histamin penyimpanan suhu $10^{\circ} \mathrm{C}$.

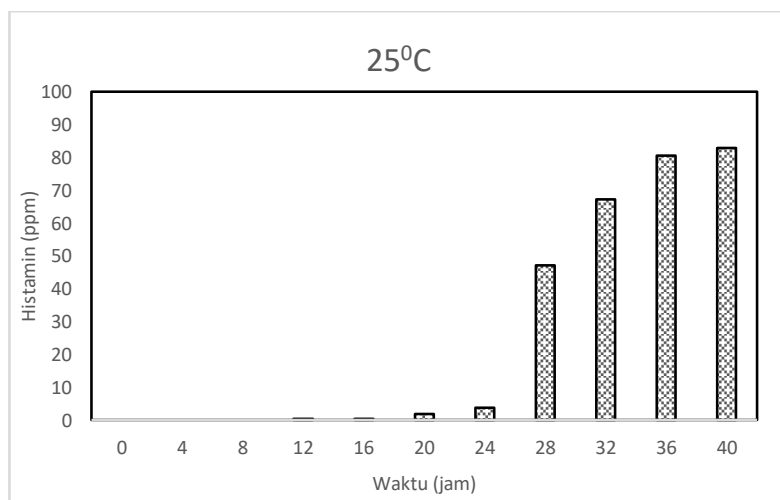

Gambar 3. Kandungan histamin penyimpanan suhu $25^{\circ} \mathrm{C}$.

\section{Angka Lempeng Total}

Total bakteri bahan baku yang digunakan adalah $1,1 \times 10^{3} \mathrm{cfu} / \mathrm{g}$. Hasil pengujian ALT mencapai $1,3 \times 10^{6} \mathrm{cfu} / \mathrm{g}$ setelah $672 \mathrm{jam}$ penyimpanan pada suhu $0^{\circ} \mathrm{C}$. Nilai ALT pada $336 \mathrm{jam}$ penyimpanan masih sangat kecil dan mulai meningkat secara bertahap setelahnya. Pada penyimpanan $10^{\circ} \mathrm{C}$ nilai ALT melebihi batas aman setelah penyimpanan selama 88 jam dengan nilai $2 \times 10^{6} \mathrm{cfu} / \mathrm{g}$ dan pada penyimpanan suhu $25^{\circ} \mathrm{C}$ nilai ALT melewati limit setelah $24 \mathrm{jam}$ penyimpanan dengan nilai 5,5 $\times 10^{5} \mathrm{cfu} / \mathrm{g}$. Output dari correlation coefficient (Pearson) didapat nilai koefisien 0,782 dan nilai signifikansi 0,000, karena koefisien mendekati 1 dan signifikansi $<0,05$ maka dapat disimpulkan bahwa antara peningkatan histamin dan jumlah total bakteri berkorelasi kuat. Hasil ALT pada Tuna sirip kuning dalam penyimpanan suhu 0, 10 dan $25^{\circ} \mathrm{C}$ dapat dilihat pada Gambar 4, 5 dan 6.

Menurut Jinadasa et al. (2015) bahwa penyimpanan Tuna sirip kuning pada suhu $<4^{\circ} \mathrm{C}$ bisa menjaga produk tetap aman untuk 2 minggu. Hal yang sama dilaporkan Widiastuti et al. (2013) bahwa Tuna steak yang disimpan pada suhu $0-4^{\circ} \mathrm{C}$ selama 15 hari nilai TPC diantara $1,9-4,4 \log$ cfu/g yang mana nilai ini masih sesuai standard, yaitu lebih kecil dari 5,7 log cfu/g (BSN,2006). Semakin banyak ikan disimpan di atas $4^{\circ} \mathrm{C}$ semakin banyak bakteri berkembang biak, dan semakin besar penurunan suhu semakin lambat bakteri berkembang biak (Starling \& Diver, 2005). Bakteri tetap akan berkembang pada penyimpanan dingin $0-3,3^{\circ} \mathrm{C}$ namun akan tumbuh dengan lambat (DiGregorio, 2012). Spanish mackerel yang disimpan pada suhu $15^{\circ} \mathrm{C}$ Total Bakteri berkembang 
secara perlahan hingga mencapai 9,48 log CFU/g setelah 5 hari penyimpanan dan mencapai 9,78 $\log$ CFU/g setelah 3 hari pada penyimpanan suhu $25^{\circ} \mathrm{C}$ (Lee et al., 2019).

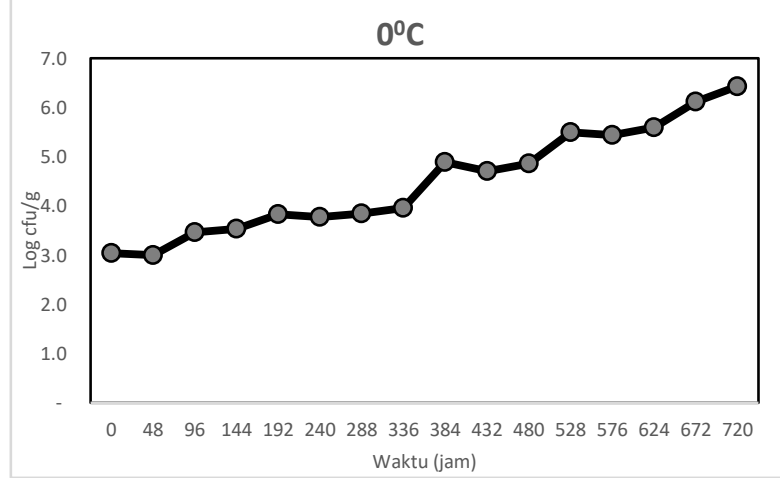

Gambar 4. Nilai ALT penyimpanan suhu $4^{\circ} \mathrm{C}$.

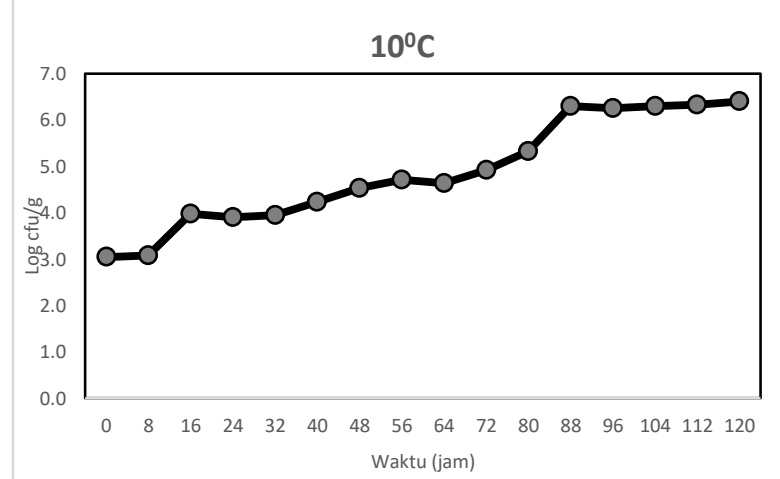

Gambar 5.Nilai ALT penyimpanan suhu $10^{\circ} \mathrm{C}$.

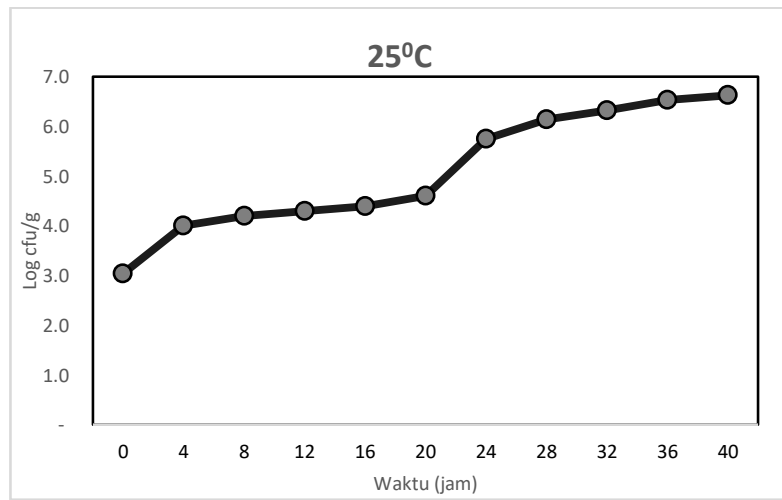

Gambar 6. Nilai ALT penyimpanan suhu $250^{\circ}$.

\section{Sensori Bau}

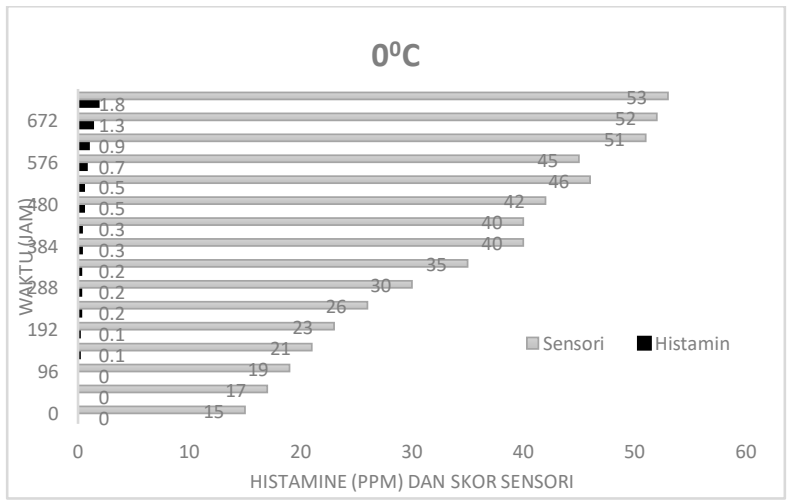

Gambar 7.Kualitas sensori dan kandungan histamin pada suhu $0-4^{\circ} \mathrm{C}$.

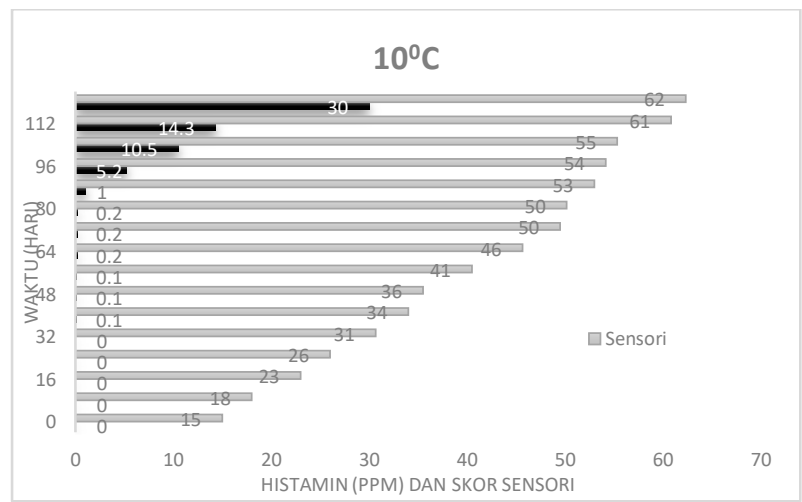

Gambar 8. Kualitas sensori dan kandungan histamin pada suhu $10^{\circ} \mathrm{C}$.

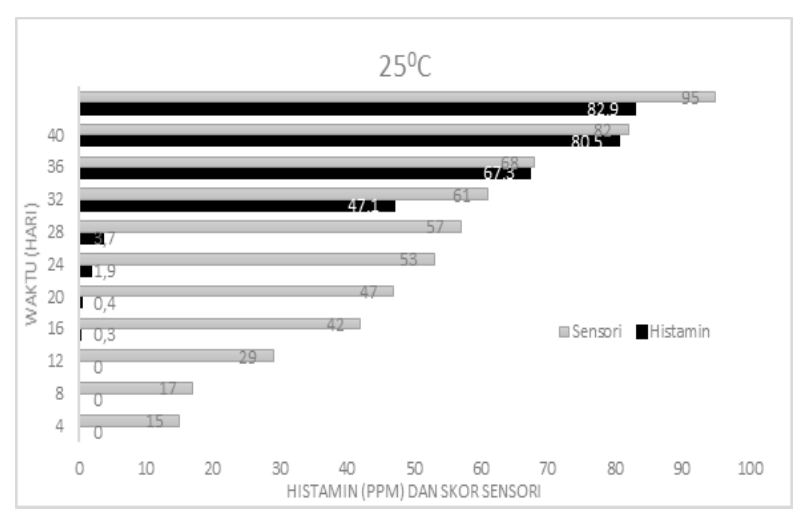

Gambar 9. Kualitas sensori dan kandungan histamin pada suhu $25^{\circ} \mathrm{C}$. 
Nilai sensori bau bahan baku yang digunakan adalah 15 dimana ini masuk kategori high pass. Penyimpanan pada suhu $0^{\circ} \mathrm{C}$ nilai sensori bau terdeteksi busuk setelah penyimpanan selama 624 jam dan pada penyimpanan suhu $10^{\circ} \mathrm{C}$ nilai sensori bau dinyatakan busuk setelah penyimpanan selama 72 jam sedangkan pada suhu $25^{\circ} \mathrm{C}$ ikan mulai busuk setelah penyimpan selama 24 jam. Output dari correlation coefficient (Pearson) didapat nilai koefisien 0,742 dan nilai signifikansi 0,000, karena koefisien mendekati 1 dan signifikansi <0,05 maka dapat disimpulkan bahwa antara peningkatan histamin dan penurunan mutu sensori bau berkorelasi kuat. Hasil nilai korelasi sensori bau pada perlakuan penyimpanan 0,10 dan $25^{\circ} \mathrm{C}$ dapat dilihat pada Gambar 7,8, dan 9.

Berdasarkan semua perlakuan penyimpanan, kemunduran mutu berdasarkan parameter sensori bau terdeteksi lebih awal dibandingkan pembentukan histamin. Menurut Sabater et al. (1996) nilai sensori lebih cepat melebihi batas limit aman untuk dikonsumsi sebelum kandungan histamin mencapai level 50 ppm dan sesuai dengan Jinadasa et al. (2015) dan Guizani et al. (2005) Tuna sirip kuning dinyatakan lebih dulu busuk berdasarkan parameter sensori. Menurut Silbande et al. (2016) Tuna steak tidak bisa dikonsumsi setelah 13 hari penyimpanan. Korelasi antara kandungan histamin dan bau sering tidak konsisten (FAO/WHO, 2012), seperti terdeteksi bau tanpa peningkatan histamin (Du et al., 2002).

\section{KESIMPULAN}

Suhu dan waktu simpan sangat berpengaruh terhadap peningkatan histamin, pertumbuhan bakteri dan penurunan mutu sensori bau. Penyimpanan dalam suhu $0^{\circ} \mathrm{C}$ peningkatan histamin dapat diabaikan hingga 720 jam penyimpanan. Parameter sensori bau lebih awal mendeteksi ikan busuk dibandingkan parameter ALT maupun histamin. Terjadi korelasi antara peningkatan histamin dengan pertumbuhan jumlah total bakteri dan penurunan nilai sensori bau.

\section{DAFTAR PUSTAKA}

[BSN] Badan Standardisasi Nasional. (2006). Tuna beku-Bagian 1: Spesifikasi. SNI 01-2710.1:2006. Jakarta: BSN.

[BSN] Badan Standardisasi Nasional. (2015). Cara Uji Mikrobiologi-Bagian 3: Penentuan Angka Lempeng Total (ALT) pada produk perikanan. SNI 2332.3:2015. Jakarta : BSN.

Biji, K. B., Ravishankar, C. N., Venkateswarlu, R., Mohan, C. O., \& Gopal, T. K. S. (2016). Biogenic amines in seafood: a review. Journal of Food Science and Technology, 53 (5), 2210-2218. https://doi.org/10.1007/s13197016-2224-x

Cinquina, A. L., Longo, F., Calì, A., De Santis, L., Baccelliere, R., \& Cozzani, R. (2004). Validation and comparison of analytical methods for the determination of histamine in tuna fish samples. Journal of Chromatography A, 1032 (1-2), 79-85. https://doi.org/10.1016/j.chroma.2003.11.033

DiGregorio, R. (2012). Tuna Grading and Evaluation: The complete Tuna Buyer's Handbook (M. Zicarellu (ed.)). Urner Barry.

Du, W. X., Lin, C. M., Phu, A. T., Cornell, J. A., Marshall, M. R., \& Wei, C. I. (2002). Development of biogenic amines in Tuna sirip kuning (Thunnus albacares): Effect of storage and correlation with decarboxylase-positive bacterial flora. Journal of Food Science, 67 (1), 292-301. https://doi.org/10.1111/j.1365-2621.2002.tb11400.x

[FAO] Food and Agriculture Organization. (2019). Globefish Higlights: A Quaterly Update on World Seafood Markets. In FAO.

[FAO] Food and Agriculture Organization/[WHO] World Health Organization. (2012). Joint FAO/WHO Expert Meeting on the Public Health Risks of Histamine and Other Biogenic Amines from Fish and Fishery Products. FAO/WHO. https://doi.org/10.1080/10601321003659457 M4 - Citavi

[FDA] U.S. Food and Drug Administration. (2019). Fish and Fishery Products Hazards and Controls Guidance - Fourth Edition. In Fish and Fishery Products Hazard and Control Guidance Fourth Edition. https://doi.org/10.1039/9781847558398-00136

Guizani, N., Al-Busaidy, M. A., Al-Belushi, I. M., Mothershaw, A., \& Rahman, M. S. (2005). The effect of storage temperature on histamine production and the freshness of Tuna sirip kuning (Thunnus albacares). Food Research International, 38 (2), 215-222. https://doi.org/10.1016/j.foodres.2004.09.011

Hansamali, L. H. D., Ranatunga, R. R. M. K. P., Buddhinie, P. K. C., \& Ashoka, P. (2020). Determination of shelf life of Tuna sirip kuning (Thunnus albacares) with regard to microbial count, histamine level and flesh colour. Sri Lanka Journal of Aquatic Sciences, 25 (1), 1-8. https://doi.org/10.4038/sljas.v25i1.7571

Irawati, H., Kusnandar, F., \& D Kusumaningrum, H. (2019). Analisis Penyebab Penolakan Produk Perikanan Indonesia oleh Uni Eropa Periode 2007-2017 dengan Pendekatan Root Cause Analysis. Jurnal Standardisasi, 21(2), 149. https://doi.org/10.31153/js.v21i2.757 
Jinadasa, B. K. K. K., Galhena, C. K., \& Liyanage, N. P. P. (2015). Histamine formation and the freshness of Tuna sirip kuning (Thunnus albacares) stored at different temperatures. Cogent Food \& Agriculture, 1 (1). https://doi.org/10.1080/23311932.2015.1028735

Lee, Y. C., Tseng, P. H., Hwang, C. C., Kung, H. F., Huang, Y. L., Lin, C. Saint, Wei, C. I., \& Tsai, Y. H. (2019). Effect of Vacuum Packaging on Histamine Production in Japanese Spanish Mackerel (Scomberomorus niphonius) Stored at Various Temperatures. Journal of Food Protection, 82 (11), 1931-1937. https://doi.org/10.4315/0362028X.JFP-19-143

Lehane, L., \& Olley, J. (2000). Histamine fish poisoning revisited. In International Journal of Food Microbiology. https://doi.org/10.1016/S0168-1605(00)00296-8

López-Sabater, E. I., Rodríguez-Jerez, J. J., Hernádez-Herrero, M., Roig-Sagués, A. X., \& Mora-Ventura, M. T. (1996). Sensory quality and histamine formation during controlled decomposition of tuna (Thunnus thynnus). Journal of Food Protection, 59 (2), 167-174. https://doi.org/10.4315/0362-028X-59.2.167

Mahusain, N. A. S., Bayoi, F., Karim, N. U., Zainol, M. K., \& Danish-Daniel, M. (2016). Determination of histamine levels in long-tail tuna (Thunnus tonggol) stored at different temperature. https://doi.org/10.7287/peerj.preprints. 2360

Mangunwardoyo, W., Sophia, R. A., \& Heruwati, E. S. (2007). Seleksi dan Pengujian Aktivitas Enzim L-Histidine Decarboxylase dari Bakteri Pembentuk Histamin. MAKARA of Science Series, 11 (2), 104-109. https://doi.org/10.7454/mss.v11i2.292

Maulana, H., Afrianto, E., \& Rustikawati, I. (2012). Analisis bahaya dan penentuan titik pengendalian kritis pada penanganan tuna segar utuh di PT. Bali Ocean Anugrah Linger Indonesia Benoa-Bali. Jurnal Perikanan Kelautan, $3(4), 1-5$.

Nurjanah, Asadatun, A., \& Kustiariyah. (2011). Pengetahuan dan Karakteristik Bahan Baku Hasil Perairan. IPB Press.

Silbande, A., Adenet, S., Smith-Ravin, J., Joffraud, J. J., Rochefort, K., \& Leroi, F. (2016). Quality assessment of icestored tropical Tuna sirip kuning (Thunnus albacares) and influence of vacuum and modified atmosphere packaging. Food Microbiology, 60 (2016), 62-72. https://doi.org/10.1016/j.fm.2016.06.016

Starling, E., \& Diver, G. (2005). The Australian tuna handling manual: a practical guide for industry. Seafood Services Australia.

Tahmouzi, S., Ghasemlou, M., Aliabadi, F. S., Shahraz, F., Hosseini, H., \& Khaksar, R. (2013). Histamine formation and bacteriological quality in skipjack tuna (Katsuwonus pelamis): Effect of defrosting temperature. Journal of Food Processing and Preservation, 37 (4), 306-313. https://doi.org/10.1111/j.1745-4549.2011.00650.x

Tao, Z., Nakano, T., Yamaguchi, T., \& Sato, M. (2002). Production and diffusion of histamine in the muscle of scombroid fishes. Fisheries Science, 68, 1394-1397. https://doi.org/10.2331/fishsci.68.sup2_1394

Widiastuti, I., Putro, S., Fardiaz, D., Trilaksani, W., \& Inaoka, T. (2013). Changes in freshness of steak and loin tuna (Thunnus albacares) during 15 day-chilled storage. Journal of Fisheries and Aquatic Science, 8 (2), $367-377$. https://doi.org/10.3923/jfas.2013.367.377

Wodi, S. I. M., Cahyono, E., \& Mamontho, N. (2016). Mutu Ikan Pindang Selar (Selaroides Sp.) pada Berbagai Konsentrasi Ekstrak Daun Kemangi. Jurnal Ilmiah Tindalung, 2(1), 36-41.

Wodi, S. I. M., Trilaksani, W., \& Nurilmala, M. (2018). Histamin dan Identifikasi Bakteri Pembentuk Histamin pada Tuna Mata Besar (Thunnus obesus). Jurnal Teknologi Perikanan Dan Kelautan Vol, 9(2), 185-192. 